\title{
EVALUATION OF PROGNOSTIC FACTORS IN QUALITY OF LIFE OF PATIENTS WITH ADOLESCENT IDIOPATHIC SCOLIOSIS UNDERGOING SPINAL FUSION BY THE POSTERIOR APPROACH
}

\author{
AVALIAÇÃO DE FATORES PROGNÓSTICOS NA QUALIDADE DE VIDA DE PACIENTES COM \\ ESCOLIOSE IDIOPÁTICA DO ADOLESCENTE SUBMETIDOS À ARTRODESE DA COLUNA POR \\ VIA POSTERIOR
}

\author{
EVALUACIÓN DE FACTORES PRONÓSTICOS EN LA CALIDAD DE VIDA DE LOS PACIENTES \\ CON ESCOLIOSIS IDIOPÁTICA DEL ADOLESCENTE SOMETIDOS A LA ARTRODESIS ESPINAL \\ POR VIA POSTERIOR
}

Felipe de Moraes Pomar ${ }^{1}$, Daphine de Carvalho Sousa ${ }^{1}$, Alberto Ofenhejm Gotrryd ${ }^{1}$, Nicola Jorge Carneiro ${ }^{1}$

1. Santa Casa de Misericórdia de Santos, Department of Orthopedics andTraumatology, Spine Group, Santos, SP, Brazil.

\begin{abstract}
Objective: To evaluate the prognostic factors in the treatment of patients diagnosed with adolescent idiopathic scoliosis undergoing spinal fusion by the posterior approach. Methods: The study included 48 patients with idiopathic adolescent scoliosis (43 females and 5 males) who underwent spinal fusion by the posterior approach, with an average age at diagnosis of 12 years, and clinical signs of Risser between 3 and 4 at the time of surgery. Clinical and radiographic measurements were performed, the participants answered the SRS-30 questionnaire, and the analysis of the medical record data was performed in two occasions during the preoperative period and at the end of two years of follow-up. Results: All satisfaction measures showed statistically significant change after the procedure $(p<0.05)$ with respect to the radiographic characteristics, except for the lumbar apical vertebral translation $(p=0.540)$ and Cobb L1-L5 $(p=0.225)$. Conclusion: In general, it was found that patients who received surgical treatment were more satisfied with their appearance than those who underwent conservative treatment.
\end{abstract}

Descritores: Scoliosis; Arthrodesis; Quality of life.

\section{RESUMO}

Objetivo: Avaliar os fatores prognósticos do tratamento de pacientes diagnosticados com escoliose idiopática do adolescente submetidos à artrodese da coluna por via posterior. Métodos: Participaram do estudo 48 pacientes portadores de escoliose idiopática do adolescente (43 do sexo feminino e 5 do sexo masculino), submetidos à artrodese da coluna por via posterior, com média de idade de 12 anos ao diagnóstico e com sinal clínico de Risser entre 3 e 4 no momento da cirurgia. Foram realizadas medições clínicas e radiográficas, aplicou-se o questionário SRS-30 e análise de dados de prontuário dos pacientes em dois momentos: durante pré-operatório e ao final de 2 anos de seguimento. Resultados: Todas as medidas de satisfação apresentaram alteração estatisticamente significativa após o procedimento $(p<0,05)$, com relação às características radiográficas, com exceção da translação vertebral apical lombar $(p=0,540)$ e Cobb L1-L5 $(p=0,225)$. Conclusão: De maneira geral, pacientes submetidos ao tratamento cirúrgico revelam-se mais satisfeitos com sua aparência com relação aos tratados de maneira conservadora.

Descriptores: Escoliose; Artrodese; Qualidade de vida.

\section{RESUMEN}

Objetivo: Evaluar los factores pronósticos en el tratamiento de pacientes con diagnóstico de escoliosis idiopática del adolescente sometidos a fusión espinal por vía posterior. Métodos: El estudio incluyó 48 pacientes con escoliosis idiopática del adolescente (43 mujeres y 5 hombres) que se sometieron a la fusión por vía posterior, con una edad media de 12 años al momento del diagnóstico y con signos de Risser entre 3 y 4 en momento de la cirugía. Se realizaron mediciones clínicas y radiológicas, se aplicó el cuestionario SRS-30 y los datos del registro médico de los pacientes fueron analizados en dos ocasiones, durante el período preoperatorio y al cabo de dos años de seguimiento. Resultados: Todas las medidas de satisfacción mostraron cambios estadísticamente significativos después del procedimiento $(p<0,05)$, con respecto a las características radiográficas, a excepción de la traslación vertebral apical lumbar ( $p=0,540)$ y Cobb L1-L5 ( $p=0,225)$. Conclusión: En general, los pacientes sometidos a tratamiento quirúrgico se muestran más satisfechos con su aspecto comparado con el tratamiento conservador.

Descriptores: Escoliosis; Artrodesis; Calidad de vida.

\section{INTRODUCTION}

Adolescent idiopathic scoliosis (AIS) is a musculoskeletal disorder of unknown origin, considered to be the most common cause of spinal deviations and responsible for approximately $80 \%$ of all spinal deformities. ${ }^{1}$ A diagnosis is made in individuals from 11 to 18 years of age with a deformity of more than $10^{\circ}$ in the coronal plane observed in the posterior-anterior radiograph, after the exclusion of other diagnostic possibilities that present the same characteristics, 
such as, for example neuromuscular, congenital, inflammatory, functional, or tumor process changes. ${ }^{1,2}$ When not treated, it can cause progressive deformities, which, in turn, cause chronic pain, social impact, and cardiopulmonary compromise. ${ }^{3}$

AIS affects females and males at a proportion of 8:1. ${ }^{3}$ Idiopathic scoliosis can be classified radiographically by determining the pattern of the deformity (six types), of the thoracic kyphosis (three types), and of the lumbar modifier (three types), yielding 42 subtypes of the disease. Lenke type I deformities include the main structured thoracic curves and are the most common form of AIS presentation. ${ }^{4}$

An indication for surgical treatment is based on the degree of angulation of the curves and surgical correction should be performed in skeletally mature individuals when the curves are greater than $40^{\circ} .5$

The treatment consists of spinal fusion in the segments considered to be structured, i.e., with little flexibility observed in radiographs taken in the lateral inclination position. According to Lenke et al., ${ }^{4}$ curves with angular values greater than $25^{\circ}$ in the lateral inclinations are structured and, thus, should be involved in the spinal fusion. Therefore, the objective of surgery is to rebalance the trunk, to interrupt the evolution of the disease, and to improve the esthetics.

Each individual responds differently to surgical treatment. Thus, the individual situation of the subject must be taken into account, respecting their intrinsic characteristics such as psychosocial, ethnic, and gender factors, in addition to factors related to the surgical procedure performed. ${ }^{4}$

Thus, bearing in mind the small number of studies about predictive preoperative factors for the clinical results of patients with AIS who have undergone this surgical procedure, the objective of this study was to evaluate the prognostic factors for the quality of life and personal satisfaction of patients with adolescent idiopathic scoliosis submitted to posterior approach spinal fusion.

\section{METHODS}

The sample consisted of 48 subjects ( 43 females and 5 males) diagnosed with AIS who underwent posterior approach spinal fusion. The subjects averaged 12 years of age and a Risser clinical sign of between 3 and 4 at the time of surgical intervention. The inclusion criteria were patients diagnosed with AIS, between 11 and 18 years of age, with scoliotic curves between $45^{\circ}$ and $80^{\circ}$, who were submitted to posterior approach surgical intervention (arthrodesis) and with a minimum medical follow-up of two years. The exclusion criteria used were patients who underwent reoperations and for whom all the measurements selected for this study were not taken.

The scoliotic curves were measured by the Cobb Method, using panoramic radiographs of the entire spine in posterior-anterior and lateral views. The Lenke classification was used as a way to categorize the subjects, 22 of whom were classified as Lenke type $1 \mathrm{AN}$ and 12 as $1 \mathrm{BN}$.

In this study, we analyzed the data from the subject's medical records both from the preoperative period and from the two-year post-operative follow-up period. Clinical and radiographical measurements were taken and the SRS-30 questionnaire was used in the same periods, after the consent of the subjects and their respective responsible parties.

The following data were used as clinical parameters: size of the thoracic hump in centimeters, measured using the Adams Maneuver; translation of the trunk in the coronal plane measured in centimeters using the Plumb Line Test as recommended by the Scoliosis Research Society; ${ }^{6}$ height of the shoulders measured with the patients standing with their back facing the examiner, evaluating the alignment of the shoulders in relation to the contralateral limb and the horizontal plane; whether an orthopedic vest had previously been used; associated illnesses; percentage of correction; complications; age at diagnosis; sex.

The following parameters were used to evaluate the radiographic results: the Risser sign; the lumbar spine modifier as described by Lenke; ${ }^{4}$ the lumbar lordosis and thoracic kyphosis measurements using the Cobb Method; ${ }^{6}$ the percentage of correction of the principal thoracic curve $X$ the percentage of correction of the thoracolumbar/ lumbar curve, evaluated using the equation proposed by Suk et al., ${ }^{7}$ with the percentage of correction calculated using the formula;

\section{Preoperative Cobb - Postoperative Cobb x 100 preoperative Cobb}

The thoracic curve angulation ratio calculated by dividing the thoracic Cobb angle by thoracolumbar/lumbar Cobb angle; the distal level of the thoracic fusion; the thoracic apical vertebral translation (TAVT - the distance between the center of the thoracic apical vertebra and the central sacral vertical line [CSVL]); the instrumented distal vertebral inclination (IDVI); and the clavicle angle.

The SRS-30 questionnaire was administered preoperatively and at $3,6,12$, and 24 months following the surgical procedure as a means of subjective evaluation of the patients.

Statistical analysis was performed using the paired Wilcoxon test, Spearman's correlation, the Student's t-test, and multiple linear regression models, ${ }^{8}$ retaining only variables with statistical significance $(p<0.05)$ in the final model.

This study was approved by the Institutional Review Board of the institution where it was developed under opinion number 958.215.

\section{RESULTS}

All measurements of satisfaction reflected statistically significant change following the procedure $(p<0.05)$ and, with the exception of lumbar apical vertebral translation $(p=0.540)$ and Cobb L1-L5 ( $p$ $=0.225$ ), all the radiographical characteristics reflected statistically significant change with the procedure $(p<0.05)$.

We found poor correlation between the radiographical and clinical measurements and the satisfaction domains in the preoperative period. The satisfaction domain had a high correlation with the RISSER scale $(r=0.478$ and $p=0.001)$, yielding statistically significant values (values less than 0.5) and the highest correlation observed, Only the number of levels had a direct correlation with the percent change in satisfaction $(r=0.352$ and $p=0.021)$, i.e., the higher the number of levels, the higher the percent change in satisfaction.

Patients with complications had a lower percent change in the satisfaction scale $(p=0.050)$. Taken together, the plumb line test and the number of levels influenced the percent change in satisfaction. An increase of one unit in the plumb line test resulted in a reduction of $6.77 \%$ in the change in satisfaction and each one-level increase caused a $10.6 \%$ increase in the change in satisfaction. Together, the two characteristics accounted for $22.8 \%\left(R^{2}=0,228\right)$ of the variability in the percent change in satisfaction.

The personal and clinical characteristics are displayed in Table 1.

The satisfaction measurements can be observed in Table 2, all with statistically significant values following the procedure $(p<0.05)$, with the exception of lumbar apical vertebral translation $(p=0.540)$ and Cobb L1-L5 ( $p=0.225)$.

As can be seen in Table 3, there were few preoperative radiographical or clinical measurements with correlations to the preoperative satisfaction domains. The highest correlation observed was with the Risser scale $(r=0.478$ and $p=0.001)$.

The data displayed in Table 4 shows that the higher the number of levels, the higher the percent change in satisfaction $(r=0.352$ and $p=0.021$ )

Based on Table 5, we can see that patients who have complications had a lower percent change in the satisfaction scale $(p=0.050)$.

Considering Table 6 , we found that the plumb line and the number of levels influenced the change in percentage of satisfaction, with an increase of one unit in the plumb line test yielding a reduction of $6.77 \%$ in the change in satisfaction and each one-level increase causing an increase of $10.46 \%$ in the change in satisfaction. Both characteristics together accounted for $22.8 \%\left(R^{2}=0,228\right)$ of the variability in the percent change in satisfaction.

\section{DISCUSSION}

The presentation of AIS can range from milder forms, generating 
Table 1. Description of the preoperative personal and clinical characteristics of the patients.

\begin{tabular}{|c|c|}
\hline Variable & Description $(N=48)$ \\
\hline \multicolumn{2}{|l|}{ Sex, n (\%) } \\
\hline Male & $5(10.4)$ \\
\hline Female & $43(89.6)$ \\
\hline \multicolumn{2}{|l|}{ Age at diagnosis (years) } \\
\hline Mean (SD) & $11.98(1.19)$ \\
\hline Median (min.; max.) & $12(10 ; 15)$ \\
\hline \multicolumn{2}{|c|}{ Hospitalization time (days)* } \\
\hline Mean (SD) & $5.7(1.72)$ \\
\hline Median (min.; max.) & $5(4 ; 12)$ \\
\hline \multicolumn{2}{|c|}{ Age at menarche (years)* } \\
\hline Mean (SD) & $16.78(16.04)$ \\
\hline Median (min.; max.) & $12(0 ; 60)$ \\
\hline \multicolumn{2}{|l|}{ RISSER* } \\
\hline Mean (SD) & $3.51(1.08)$ \\
\hline Median (min.; max.) & $4(0 ; 5)$ \\
\hline \multicolumn{2}{|c|}{ Proximal thoracic lateral inclination } \\
\hline Mean (SD) & $13.75(8.14)$ \\
\hline Median (min.; max.) & $13.5(-6 ; 34)$ \\
\hline \multicolumn{2}{|c|}{ Principal thoracic lateral inclination } \\
\hline Mean (SD) & $33.1(19.55)$ \\
\hline Median (min.; max.) & $30(6 ; 135)$ \\
\hline \multicolumn{2}{|c|}{ Thoracolumbar lateral inclination } \\
\hline Mean (SD) & $3.87(14.27)$ \\
\hline Median (min.; max.) & $3.5(-29 ; 62)$ \\
\hline \multicolumn{2}{|l|}{ Cobb T10-L2* } \\
\hline Mean (SD) & $9.4(7.45)$ \\
\hline Median (min.; max.) & $10(-15 ; 31)$ \\
\hline \multicolumn{2}{|l|}{ KING* } \\
\hline Mean (SD) & $2.7(0.59)$ \\
\hline Median (min.; max.) & $3(1 ; 4)$ \\
\hline \multicolumn{2}{|l|}{ Surgical time (minutes) } \\
\hline Mean (SD) & $265.73(65.63)$ \\
\hline Median (min.; max.) & $240(180 ; 480)$ \\
\hline \multicolumn{2}{|l|}{ Bleeding volume } \\
\hline Mean (SD) & $685(219.85)$ \\
\hline Mean (min.; max.) & $600(400 ; 1500)$ \\
\hline \multicolumn{2}{|l|}{ Packed red cell units } \\
\hline Mean (SD) & $1.98(1.04)$ \\
\hline Median (min.; max.) & $2(0 ; 4)$ \\
\hline \multicolumn{2}{|l|}{ Number of levels* } \\
\hline Mean (SD) & $8.47(1.12)$ \\
\hline Median (min.; max.) & $8(6 ; 12)$ \\
\hline \multicolumn{2}{|l|}{ Number of screws* } \\
\hline Mean (SD) & $11.61(1.85)$ \\
\hline Median (min.; max.) & $10.5(10 ; 16)$ \\
\hline
\end{tabular}

\begin{tabular}{|c|c|}
\hline Variable & Description $(\mathrm{N}=48)$ \\
\hline \multicolumn{2}{|l|}{ Density* } \\
\hline Mean (SD) & $0.69(0.11)$ \\
\hline Median (min.; max.) & $0.71(0.5 ; 0.93)$ \\
\hline \multicolumn{2}{|l|}{ Weight $(\mathrm{Kg})^{*}$} \\
\hline Mean (SD) & $47.3(6.78)$ \\
\hline Median (min.; max.) & $48.5(35 ; 57)$ \\
\hline \multicolumn{2}{|l|}{ Height $(m)^{*}$} \\
\hline Mean (SD) & $1.58(0.09)$ \\
\hline Median (min.; max.) & $1.59(1.5 ; 1.7)$ \\
\hline \multicolumn{2}{|l|}{ BMI $(\mathrm{Kg} / \mathrm{m} 2)^{*}$} \\
\hline Mean (SD) & $19.15(3.43)$ \\
\hline Median (min.; max.) & $19.18(13.67 ; 24.26)$ \\
\hline \multicolumn{2}{|l|}{ Vest, n (\%)* } \\
\hline No & $30(63.8)$ \\
\hline Yes & $17(36.2)$ \\
\hline \multicolumn{2}{|c|}{ Associated illnesses, n (\%)* } \\
\hline No & $40(85.1)$ \\
\hline Yes & $7(14.9)$ \\
\hline \multicolumn{2}{|l|}{ LENKE, n (\%)* } \\
\hline $1 \mathrm{~A}-$ & $4(8.7)$ \\
\hline $1 \mathrm{AN}$ & $22(47.8)$ \\
\hline 1B- & $2(4.3)$ \\
\hline $1 \mathrm{~B}+$ & $1(2.2)$ \\
\hline $1 \mathrm{BN}$ & $12(26.1)$ \\
\hline $1 \mathrm{CN}$ & $2(4.3)$ \\
\hline $2 \mathrm{CN}$ & $1(2.2)$ \\
\hline $4 \mathrm{C}+$ & $1(2.2)$ \\
\hline $6 \mathrm{CN}$ & $1(2.2)$ \\
\hline \multicolumn{2}{|l|}{ Complications, n (\%) } \\
\hline No & $43(89.6)$ \\
\hline Yes & $5(10.4)$ \\
\hline \multicolumn{2}{|l|}{ Fusion level, $\mathbf{n}(\%)^{*}$} \\
\hline T3-L1 & $1(2.3)$ \\
\hline T3-L4 & $1(2.3)$ \\
\hline T4-L1 & $13(29.5)$ \\
\hline T4-L4 & $3(6.8)$ \\
\hline T4-T11 & $1(2.3)$ \\
\hline T4-T12 & $5(11.4)$ \\
\hline T4L1 & $1(2.3)$ \\
\hline T5-L1 & $12(27.3)$ \\
\hline T5-L4 & $1(2.3)$ \\
\hline T5-T12 & $2(4.5)$ \\
\hline T6-L1 & $2(4.5)$ \\
\hline T6-L3 & $1(2.3)$ \\
\hline T6-T12 & $1(2.3)$ \\
\hline
\end{tabular}

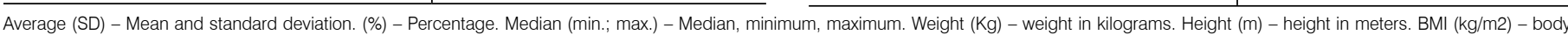
mass index - kilograms divided by meters squared. $\mathrm{N}$ - number.

some degree of misalignment in the trunk, to serious deformities with pulmonary and cardiac involvement. The impact of scoliosis on the quality of life of adolescents is variable. However, esthetic complaints and psychological and behavioral change may be found in people with AIS. ${ }^{6}$

One retrospective study ${ }^{2}$ compared 1853 children with AIS belonging to 6 different ethnic groups in the USA. Through their analysis, the authors concluded that culture and ethnicity have an influence on pre- and postoperative results and that these variations should be taken into account when counseling patients and when investigating the characteristics of AIS.
In our study, we evaluated the radiographic measurements, the measurement of levels of satisfaction according to five domains (function, pain, appearance, mental health, and satisfaction with the procedure), as well as the sum of all the SRS-30 questionnaire criteria (total value). All the measurements reflected statistically significant change after the procedure $(p<0.05)$. Additionally, practically all the radiographical characteristics showed statistically significant changes from the procedure $(p<0.05)$, with the exception of lumbar apical vertebral translation $(p=0.540)$ and of the Cobb L1-L5 angle $(p=0.225)$. The fact that neither of these radiographical lumbar measurements underwent a statistically significant change can be 
Table 2. Description of the satisfaction and pre- and postoperative radiographic measurements.

\begin{tabular}{|c|c|c|c|}
\hline Variable & Pre & $\begin{array}{c}\text { Post } \\
\text { (2 years) }\end{array}$ & p \\
\hline Hump (cm) preoperative & & & $<0.001$ \\
\hline Mean (SD) & $2.19(0.94)$ & $0.89(0.81)$ & \\
\hline Median (min.; max.) & $2(0 ; 4)$ & $0.5(0 ; 3)$ & \\
\hline Plumb line preoperative & & & $<0.001$ \\
\hline Mean (SD) & $1.24(1.24)$ & $0.28(0.63)$ & \\
\hline Median (min.; max.) & $1(0 ; 5)$ & $0(0 ; 3)$ & \\
\hline Function & & & $<0.001$ \\
\hline Mean (SD) & $18.71(3.91)$ & $25.63(4.11)$ & \\
\hline Median (min.; max.) & $19.5(10 ; 23)$ & $26(14 ; 35)$ & \\
\hline Pain & & & $<0.001$ \\
\hline Mean (SD) & $21.02(3.22)$ & $25.63(3.39)$ & \\
\hline Median (min.; max.) & $21.5(13 ; 25)$ & $26(16 ; 30)$ & \\
\hline Appearance & & & $<0.001$ \\
\hline Mean (SD) & $17.44(4.24)$ & $36.5(4.85)$ & \\
\hline Median (min.; max.) & $17.5(8 ; 28)$ & $36.5(24 ; 45)$ & \\
\hline Mental health & & & 0.002 \\
\hline Mean (SD) & $17.23(3.05)$ & $19.29(3.45)$ & \\
\hline Median (min.; max.) & $17(11 ; 23)$ & $19(13 ; 25)$ & \\
\hline Satisfaction & & & $<0.001$ \\
\hline Mean (SD) & $6.81(2.18)$ & $13.42(1.91)$ & \\
\hline Median (min.; max.) & $6(2 ; 10)$ & $14(8 ; 15)$ & \\
\hline Total SRS-30 & & & $<0.001$ \\
\hline Mean (SD) & $81.21(11.56)$ & $\begin{array}{l}120.46 \\
(11.53) \\
\end{array}$ & \\
\hline Median (min.; max.) & $80(60 ; 107)$ & $120(94 ; 147)$ & \\
\hline Cobb proximal thoracic AP curve & & & $<0.001$ \\
\hline Mean (SD) & $25.54(8.66)$ & $13.96(9)$ & \\
\hline Median (min.; max.) & $25.5(12 ; 56)$ & $11.5(2 ; 40)$ & \\
\hline Cobb principal thoracic AP curve & & & $<0.001$ \\
\hline Mean (SD) & $60.71(15.51)$ & $21.6(16.42)$ & \\
\hline Median (min.; max.) & $58(44 ; 140)$ & $20(4 ; 113)$ & \\
\hline Cobb thoracolumbar/lumbar AP curve & & & $<0.001$ \\
\hline Mean (SD) & $35.94(10.28)$ & $15.6(9.36)$ & \\
\hline Median (min.; max.) & $37(17 ; 62)$ & $15(0 ; 35)$ & \\
\hline Thoracic apical vertebral translation & & & $<0.001$ \\
\hline Mean (SD) & $50.79(22.26)$ & $15.53(18.77)$ & \\
\hline Median (min.; max.) & $50(12 ; 145)$ & $11(-4 ; 120)$ & \\
\hline Lumbar apical vertebral translation & & & 0.540 \\
\hline Mean (SD) & $15.72(15.87)$ & $15.04(13.53)$ & \\
\hline Median (min.; max.) & $13(-5 ; 84)$ & $12(0 ; 50)$ & \\
\hline $\begin{array}{c}\text { Instrumented distal vertebral } \\
\text { inclination }\end{array}$ & & & $<0.001$ \\
\hline Mean (SD) & $24.74(6.84)$ & $7.09(5.9)$ & \\
\hline Median (min.; max.) & $24.5(11 ; 45)$ & $6(0 ; 32)$ & \\
\hline Clavicle angle & & & $<0.001$ \\
\hline Mean (SD) & $5.04(4.5)$ & $1.62(2.5)$ & \\
\hline Median (min.; max.) & $4(0 ; 28)$ & $2(-4 ; 9)$ & \\
\hline Cobb T5-T12 & & & 0.011 \\
\hline Mean (SD) & $23.77(16.14)$ & 28.4 (11.94) & \\
\hline Median (min.; max.) & $20(0 ; 100)$ & $28(8 ; 82)$ & \\
\hline Cobb L1-L5 & & & 0.225 \\
\hline Mean (SD) & $44.4(9.97)$ & 42.96 (11.49) & \\
\hline Median (min.; max.) & $45(17 ; 62)$ & $43(24 ; 71)$ & \\
\hline
\end{tabular}

$\overline{\text { Mean (SD) - Average and standard deviation. \% - Percentage. Median (min.; max.) - Median, minimum }}$ and maximum. $\mathrm{cm}$ - centimeters. AP - anterior-posterior. $(\mathrm{cm})$ - centimeters. AP - anterior-posterior. explained by the scenario in which most of the curves in the study were Lenke type 1, characterized by a principal thoracic curve.

In the analysis of personal satisfaction according to qualitative personal and clinical characteristics, the following variables were compared: sex, prior use of a vest, the presence of associated illnesses, and complications. All the variables reflected a significant percent change on the satisfaction scale, however, the changes were smaller in patients with complications. The complications were paralysis of the brachial plexus, seizures, acute edema of the lungs, undrained surface seroma, and pain at the donor site of the bone graft.

An evaluation of the prior use of an orthopedic vest on the

Table 3. Results of the correlation between average satisfaction and preand postoperative radiographic measurements.

\begin{tabular}{|c|c|c|c|c|c|c|c|}
\hline \multicolumn{2}{|l|}{ Correlation } & Function & Pain & $\begin{array}{l}\text { Appea- } \\
\text { rance }\end{array}$ & $\begin{array}{l}\text { Mental } \\
\text { Health }\end{array}$ & Satisfaction & \begin{tabular}{|c|} 
Total \\
SRS- \\
30
\end{tabular} \\
\hline \multirow[t]{2}{*}{ RISSER } & $r$ & 0.048 & -0.064 & 0.035 & 0.032 & 0.478 & 0.116 \\
\hline & $p$ & 0.751 & 0.671 & 0.816 & 0.833 & 0.001 & 0.436 \\
\hline \multirow[t]{2}{*}{$\begin{array}{c}\text { Proximal tho- } \\
\text { racic lateral } \\
\text { inclination } \\
\end{array}$} & $r$ & -0.018 & -0.093 & 0.033 & 0.042 & -0.005 & -0.007 \\
\hline & $p$ & 0.901 & 0.528 & 0.823 & 0.777 & 0.973 & 0.962 \\
\hline \multirow[t]{2}{*}{$\begin{array}{l}\text { Principal tho- } \\
\text { racic lateral } \\
\text { inclination }\end{array}$} & $r$ & -0.058 & -0.134 & -0.099 & -0.050 & 0.188 & -0.075 \\
\hline & $p$ & 0.697 & 0.362 & 0.502 & 0.737 & 0.201 & 0.612 \\
\hline \multirow[t]{2}{*}{$\begin{array}{c}\text { Thoracolum- } \\
\text { bar lateral } \\
\text { inclination } \\
\end{array}$} & $r$ & 0.028 & -0.035 & 0.024 & 0.006 & 0.044 & 0.025 \\
\hline & $p$ & 0.850 & 0.812 & 0.870 & 0.968 & 0.767 & 0.868 \\
\hline \multirow[t]{2}{*}{$\begin{array}{l}\text { Cobb T10-L2 } \\
\end{array}$} & $r$ & -0.205 & -0.243 & -0.181 & -0.211 & -0.066 & -0.255 \\
\hline & $p$ & 0.167 & 0.100 & 0.224 & 0.155 & 0.660 & 0.083 \\
\hline \multirow[t]{2}{*}{ KING } & $r$ & 0.216 & 0.114 & -0.062 & 0.110 & -0.028 & 0.113 \\
\hline & $p$ & 0.150 & 0.449 & 0.682 & 0.467 & 0.853 & 0.453 \\
\hline \multirow[t]{2}{*}{$\begin{array}{l}\text { Hump }(\mathrm{cm}) \\
\text { preoperative }\end{array}$} & $r$ & -0.195 & -0.222 & 0.061 & 0.089 & 0.139 & -0.041 \\
\hline & $p$ & 0.185 & 0.129 & 0.681 & 0.548 & 0.346 & 0.782 \\
\hline \multirow[t]{2}{*}{$\begin{array}{c}\text { Plumb Line } \\
\text { preoperative }\end{array}$} & $r$ & 0.313 & 0.376 & 0.260 & 0.215 & -0.181 & 0.322 \\
\hline & $p$ & 0.030 & 0.008 & 0.074 & 0.142 & 0.219 & 0.026 \\
\hline \multirow[t]{2}{*}{$\begin{array}{l}\text { Cobb proxi- } \\
\text { mal thoracic } \\
\text { AP curve }\end{array}$} & $r$ & -0.022 & -0.165 & -0.279 & -0.177 & 0.037 & -0.170 \\
\hline & $p$ & 0.884 & 0.262 & 0.055 & 0.228 & 0.804 & 0.247 \\
\hline \multirow[t]{2}{*}{$\begin{array}{c}\text { Cobb princi- } \\
\text { pal thoracic } \\
\text { AP curve } \\
\end{array}$} & $r$ & -0.179 & -0.190 & -0.178 & -0.007 & 0.264 & -0.130 \\
\hline & $p$ & 0.222 & 0.197 & 0.227 & 0.965 & 0.069 & 0.379 \\
\hline \multirow[t]{2}{*}{$\begin{array}{c}\text { Cobb thora- } \\
\text { columbar/ } \\
\text { lumbar AP } \\
\text { curve } \\
\end{array}$} & $r$ & -0.140 & -0.206 & 0.119 & -0.091 & -0.080 & -0.106 \\
\hline & $p$ & 0.344 & 0.161 & .420 & 0.539 & 0.587 & 0.473 \\
\hline \multirow[t]{2}{*}{$\begin{array}{l}\text { Thoracic api- } \\
\text { cal vertebral } \\
\text { translation } \\
\end{array}$} & $r$ & -0.069 & 0.085 & -0.085 & 0.106 & 0.355 & 0.053 \\
\hline & $p$ & 0.643 & 0.565 & 0.567 & 0.475 & 0.013 & 0.721 \\
\hline \multirow[t]{2}{*}{$\begin{array}{c}\text { Lumbar api- } \\
\text { cal vertebral } \\
\text { translation } \\
\end{array}$} & $r$ & -0.070 & -0.163 & 0.034 & -0.094 & 0.059 & -0.028 \\
\hline & $p$ & 0.643 & 0.272 & 0.821 & 0.530 & 0.691 & 0.850 \\
\hline \multirow[t]{2}{*}{$\begin{array}{c}\text { Instrumented } \\
\text { distal verte- } \\
\text { bral inclina- } \\
\text { tion } \\
\end{array}$} & $r$ & -0.016 & -0.197 & 0.072 & 0.031 & 0.115 & 0.000 \\
\hline & $p$ & 0.918 & 0.190 & 0.635 & 0.835 & 0.447 & 0.999 \\
\hline \multirow[t]{2}{*}{ Clavicle angle } & $r$ & -0.254 & -0.126 & -0.033 & 0.128 & 0.265 & -0.078 \\
\hline & $p$ & 0.082 & 0.393 & 0.825 & 0.386 & 0.069 & 0.596 \\
\hline \multirow[t]{2}{*}{ Cobb T5-T12 } & $r$ & -0.240 & -0.136 & -0.236 & 0.001 & 0.182 & -0.160 \\
\hline & $p$ & 0.100 & 0.355 & 0.106 & 0.992 & 0.216 & 0.277 \\
\hline \multirow[t]{2}{*}{ Cobb L1-L5 } & $r$ & -0.052 & 0.047 & -0.024 & -0.089 & 0.202 & 0.022 \\
\hline & $p$ & 0.726 & 0.749 & 0.873 & 0.547 & 0.169 & 0.880 \\
\hline
\end{tabular}


Table 4. Results of the correlations between the changes in the satisfaction questionnaire ( 2 years - preoperative) and the preoperative radiographical and clinical measurements.

\begin{tabular}{|c|c|c|c|}
\hline Variable & Correlation & $\mathbf{N}$ & p \\
\hline Age at diagnosis (years) & 0.016 & 48 & 0.916 \\
\hline Hospitalization time (days) & 0.227 & 47 & 0.126 \\
\hline RISSER & -0.179 & 47 & 0.228 \\
\hline Proximal thoracic lateral inclination & -0.119 & 48 & 0.419 \\
\hline $\begin{array}{c}\text { Principal thoracic lateral inclination } \\
\text { principal }\end{array}$ & 0.003 & 48 & 0.984 \\
\hline Thoracolumbar lateral inclination & -0.094 & 48 & 0.525 \\
\hline Cobb T10-L2 & 0.078 & 47 & 0.601 \\
\hline KING & -0.030 & 46 & 0.843 \\
\hline HUMP $(\mathrm{cm})$ preoperative & -0.061 & 48 & 0.681 \\
\hline Plumb Line preoperative & -0.200 & 48 & 0.173 \\
\hline Surgical time (minutes) & 0.083 & 48 & 0.574 \\
\hline Bleed volume & 0.147 & 48 & 0.320 \\
\hline Packed red cell units & 0.090 & 48 & 0.542 \\
\hline Number of levels & 0.352 & 43 & 0.021 \\
\hline Number of screws & 0.141 & 44 & 0.361 \\
\hline Density & -0.129 & 39 & 0.433 \\
\hline Weight $(\mathrm{Kg})$ & 0.213 & 10 & 0.555 \\
\hline Height (m) & 0.195 & 10 & 0.590 \\
\hline $\mathrm{BMI}(\mathrm{Kg} / \mathrm{m} 2)$ & 0.127 & 10 & 0.726 \\
\hline Cobb proximal thoracic AP curve & 0.065 & 48 & 0.661 \\
\hline Cobb principal thoracic AP curve & 0.023 & 48 & 0.875 \\
\hline Cobb thoracolumbar/lumbar AP curve & -0.005 & 48 & 0.974 \\
\hline Thoracic apical vertebral translation & -0.066 & 48 & 0.654 \\
\hline Lumbar apical vertebral translation & -0.134 & 47 & 0.369 \\
\hline Instrumented distal vertebral inclination & 0.013 & 46 & 0.933 \\
\hline CLAVICLE ANGLE & 0.117 & 48 & 0.430 \\
\hline Cobb T5-T12 & 0.069 & 48 & 0.639 \\
\hline Cobb L1-L5 & -0.045 & 48 & 0.759 \\
\hline
\end{tabular}

$\overline{(\mathrm{cm})}$ - centimeters. Weight $(\mathrm{Kg})$ - weight in kilograms. Height $(\mathrm{m})$ - height in meters. AP - anteriorposterior.

postoperative results showed that it had no influence on satisfaction with the procedure, with both groups scoring high rates of percent change on the satisfaction scale. With the same objective, Lenke et al. ${ }^{4}$ compared the results of the SRS-30 and SAQ questionnaires filled out preoperatively by both patients who had and had not previously used a vest (281 and 328 , respectively). Their study found that patients who had previously used a vest, in addition to being more concerned about the appearance of the spine, had more pain, a lower activity level, less satisfaction, and a lower total score in the SRS-30 after two years of postoperative follow-up, in relation to those who had not used a vest, suggesting a negative impact from the use of this equipment in the preoperative phase on personal satisfaction at the end of treatment.
Table 5. Description of the percent change in satisfaction by qualitative personal and clinical preoperative characteristics and results of the comparative tests.

\begin{tabular}{c|c|c|c|c|c|c|c}
\hline Variable & Mean & SD & Median & Minimum & Maximum & $\mathbf{N}$ & $\mathbf{p}$ \\
\hline Sex & & & & & & & 0.770 \\
\hline Male & 54.72 & 43.10 & 32.29 & 24.21 & 126.15 & 5 & \\
\hline Female & 50.96 & 24.95 & 46.75 & -6.93 & 122.95 & 43 & \\
\hline Vest & & & & & & & 0.852 \\
\hline No & 51.15 & 29.02 & 41.86 & -6.93 & 126.15 & 30 & \\
\hline Yes & 49.62 & 22.26 & 48.05 & 17.76 & 91.43 & 17 & \\
\hline $\begin{array}{c}\text { Associated } \\
\text { illnesses }\end{array}$ & & & & & & & 0.095 \\
\hline No & 47.90 & 24.58 & 41.86 & -6.93 & 122.95 & 40 & \\
\hline Yes & 66.03 & 33.77 & 71.43 & 24.21 & 126.15 & 7 & \\
\hline Complications & & & & & & & 0.050 \\
\hline No & 52.69 & 27.83 & 47.56 & -6.93 & 126.15 & 43 & \\
\hline Yes & 39.80 & 9.57 & 38.10 & 27.38 & 54.02 & 5 & \\
\hline
\end{tabular}

SD - standard deviation.

Table 6. Identification of the preoperative characteristics that influenced the change in percent satisfaction.

\begin{tabular}{c|c|c|c|c|c}
\hline Factor & Coefficient & $\begin{array}{c}\text { Standard } \\
\text { error }\end{array}$ & t value & $\mathbf{p}$ & $\mathbf{R 2}$ \\
\hline Constant & -28.77 & 27.51 & -1.05 & 0.302 & 0.228 \\
\hline $\begin{array}{c}\text { Plumb Line } \\
\text { preoperative }\end{array}$ & -6.77 & 2.99 & -2.27 & 0.029 & \\
\hline Number of levels & 10.46 & 3.33 & 3.14 & 0.003 & \\
\hline
\end{tabular}

PLUMB LINE Pre - preoperative plumb line

In general, patients who undergo surgical treatment are more satisfied with their appearance than patients treated conservatively. However, some authors argue that the benefits of a surgical procedure can be minimal when personal satisfaction is evaluated postoperatively. In contrast to the over-indication of surgery, Herkowitz et al. ${ }^{2}$ point out that, after two years of follow-up in 745 patients with AIS who had undergone arthrodesis, they found that surgical correction in the adolescent population can have a limited impact on self-image, mental health, and satisfaction when compared to the greater role that psychological, sociocultural, and biopsychological factors perform. Through application of the SRS-24 questionnaire, they compared three groups of patients with AIS (preoperative, two years postoperative, and non-operated) and they found that spinal fusion had an isolated negative effect on the quality of life (total score), mainly due to a reduced score in the activity domain and that the overall positive effect of the surgery depends on the individual effect of the spinal fusion and the reduction of deformity. ${ }^{7}$

Data analysis of the various questionnaires applied to AIS indicates the presence of limitations that restrict the results of the study to the extent that there is little flexibility for the responses in several domains. Even though there were statistically significant changes in all the SRS domains when preoperative and two year postoperative values were compared, there are only from a few to a moderate number of associations between the changes in any given domain and treatment satisfaction. ${ }^{3}$ The author suggests that this may be attributed to the "ceiling effect" in the satisfaction domain, the low responsiveness of the SRS-22 for measuring relevant clinical changes in activity, pain, and mental health, or a true lack of changes two years after correction of scoliosis in the adolescent population. ${ }^{3}$

\section{CONCLUSION}

The study enabled the identification of prognostic factors that influence personal satisfaction and quality of life outcomes in patients who 
underwent posterior approach spinal fusion. The factors that revealed the greatest influence on the results were the preoperative Risser, the number of fused vertebral levels, and the presence of complications.

In general, patients who undergo surgical treatment are more satisfied with their appearance than those treated conservatively. Therefore, when surgical correction is indicated to treat AIS, posterior approach spinal fusion is a safe option with excellent short-and middle-term (up to 2 years postoperatively) results.

All the authors declare that there are no conflicts of interest regarding this article.

CONTRIBUTIONS OF THE AUTHORS: Each author made significant individual contributions to the development of the manuscript. AGNJ and FM performed the surgery, monitored the patients, and gathered the clinical data. FM and DC conducted the statistical analysis of the data, did the bibliographical research, reviewed the manuscript, and contributed to the intellectual concept of the study.

\section{REFERENCES}

1. National Institute of Arthritis and Musculoskeletal and Skin Diseases (NHI) Questions and answers about Raynaud's Phenomenon. Disponível em: http:// www.niams.nih.gov/health info/Raynauds Phenomenon/default.asp

2. Herkowitz HN, Garfin SR, Eismont FJ, Bell GR, Balderston RA. Rothman- simeone the spine: expert consult Philadelphia: Elsevier; 2011.

3. Bunnell WP. The natural history of idiopathic scoliosis before skeletal maturity. Spine (Phila Pa 1976). 1986;11(8):773-6.

4. Lenke LG, Betz RR, Harms J, Bridwell KH, Clements DH, Lowe TG, et al. Adolescent idiopathic scoliosis: a new classification to determine extent of spinal arthrodesis. J Bone Joint Surg Am. 2001;83-A(8):1169-81.

5. Bradford DS, Lonstein J, Moe J, Ogivie J, Winter R. Escoliose e outras deformidades da coluna: o livro de Moe. São Paulo: Santos;1994.

6. Cobb J. Outline for the study of scoliosis. Instr Course Lect. 1948;5:261-75.

7. Suk SI, Lee CK, Kim WJ, Chung YJ, Park YB. Segmental pedicle screw fixation in the treatment of thoracic idiopathic scoliosis. Spine (Phila Pa 1976). 1995;20(12):1399-405.

8. Neter J, Kutner MH, Nachtsheim CJ, Wasserman W. Applied linear statistical models Chicago: Irwin; 1996. 